\title{
Community Based Natural Resource Management, Tourism and Poverty Alleviation in Southern Africa: What Works and What Doesn’t Work
}

\author{
Percy Mabvuto Ngwira \\ Universidad Nebrija, Madrid, Spain \\ Oluwatoyin Dare Kolawole, Joseph E. Mbaiwa \\ University of Botswana, Maun, Botswana
}

\begin{abstract}
Community based natural resource management (CBNRM) is perhaps the most important tool for driving community and rural development in southern Africa. The paper therefore analyses the CBNRM framework as a strategy for implementing sustainable tourism and poverty alleviation initiatives in Botswana, Namibia, and Zambia. The article specifically underscores the importance of local-level participatory management and utilisation of natural resources in the region. Paying special attention to the previous researches that have been conducted in Botswana, Namibia, and Zambia, the methodological approach employed in the paper centres on critical discourse analysis and review of literatures to highlight the interface existing between CBNRM and rural (tourism) development. The analytical framework of the paper is thus rooted in the Common Property Resource (CPR) theory. Overall, the authors argue that tourism, poverty alleviation, rural development, and sustainable natural resource use are linked and interrelated in the process of enhancing community well-being. Findings indicate that CBNRM initiatives have had a significant and positive impact in achieving sustainable tourism, rural development, poverty alleviation, and natural resource management. Specifically, findings show that the CBNRM has contributed to the reduction in wildlife poaching. While other pertinent issues remain, national governments in the three southern African economies need to fully appropriate the benefits that CBNRM offers and improve on them for better implementation of developmental programs.
\end{abstract}

Keywords: community, institutions, common property, local knowledge, rural development, southern Africa

\section{Introduction}

Natural resources are the most significant drivers of rural livelihoods. However, the relationship between humans and natural resources is generally impactful and dependency-oriented. While on the one hand, humans are generally highly dependent on the quality and availability of natural resources, they, on the other hand,

Percy Mabvuto Ngwira, Ph.D. Candidate, Nebrija Business School, Universidad Nebrija.

Oluwatoyin Dare Kolawole, Senior Research Scholar in Rural Development, Okavango Research Institute, University of Botswana.

Joseph E. Mbaiwa, Professor of Tourism Studies, Okavango Research Institute, University of Botswana.

Correspondence concerning this article should be addressed to Percy Mabvuto Ngwira, Universidad Nebrija, Nebrija Business School Doctoral Program in Tourism UNWTO TedQual Approved Campus de Dehesa de la Villa, C/ Pirineos, 55, 28040, Spain. E-mail: tngwira@gmail.com. 
significantly impact on these resources in a manner that threatens their sustainability. One of the most significant developments in natural resource governance in southern Africa has been the integration of communities into their (natural resources) management (Jones, 2002; Mbaiwa, 2011). Jones (1999) stated that the last decade or more has witnessed a growing focus on social, economic, and environmental research in natural resources management (NRM) leading to the emergence of community based natural resource management (CBNRM). More recently, tourism development and increasing efforts at achieving rural economic integration have influenced growing enthusiasm in CBNRM by many governments, Non-Governmental Organization (NGOs), donors, and the private sector in their bid to achieve sustainable utilisation of natural resources.

However, effective management of natural resources has not always been easy to achieve. Mbaiwa (2011) argued that the CBNRM approach is built upon common property theory. Common property theory is rooted in the notion that common pool resources can be utilised sustainably, provided that certain principles are applied. Mbaiwa (2011) and Bromley (1992) stated that these principles include the autonomy and the recognition of the community as an institution, proprietorship and usufruct, rights to make the rules and viable mechanisms to enforce them as well as on-going incentives in the form of benefits that exceed costs. In other words, CBNRM programs in southern Africa are based on the understanding of these principles. Central to the CBNRM programs are the theory and assumptions underlying the political decentralisation of natural resources (Mbaiwa, 2011). Proponents of CBNRM argue that the management of resources by the central government has led to their frequent and chronic declines in the past several decades (for example, Boggs, 2000). As a result, the decentralisation of resources to local communities has the potential to promote conservation and rural development. Conservationists and scholars perceive the decentralisation of natural resources as a remedy to the chronic natural resources decline resulting from the central government's failure in ensuring effective resource management (Mbaiwa, 2011). The questions of what resources constitute the components of CBNRM programs and why they are; how appropriate and sustainable is the reliance on tourism industry for communities implementing CBNRM programs; what the effects of CBNRM on rural development and poverty alleviation are; and what study gaps still exist in CBNRM studies are answered in the paper.

Overall, the paper analyses the CBNRM framework as a strategy for driving sustainable tourism and poverty alleviation initiatives in southern African countries. The paper critically reviews past CBNRM-related studies in Botswana, Namibia, and Zambia (see Figure 1).

\section{The Study Focus}

Special attentions are paid on Botswana, Namibia, and Zambia in southern African region. Botswana is selected because of its continuous programs in CBNRM and its richness in wildlife, which is the main catalyst of CBNRM in the country. Some scholars argue that the numbers of wildlife species in Botswana have declined significantly in recent decades (Barnes, 1998; Moganane \& Walker, 1995; Mordi, 1991; Perkins, 1996; Perkins \& Ringrose, 1996). However, Mbaiwa (2011) opined that Botswana is one of the few countries in southern Africa that is still endowed with a variety of wildlife resources. As such, CBNRM in Botswana largely involves wildlife-based tourism activities such as photography and safari hunting (Mbaiwa, 2011). Namibia is also chosen as a component of the analysis in the paper because its CBNRM programs have been well researched and documented. Indeed, it is the only country that has embraced CBNRM in all its national development plans (Boudreaux \& Nelson, 2011). In spite of its slow evolution, Zambia's CBNRM is also analysed because of its 
uniqueness; Zambia's CBNRM has been integrative in nature, transiting from the wildlife sector to focusing on other natural resources like forestry and fisheries (USAID, 2011).

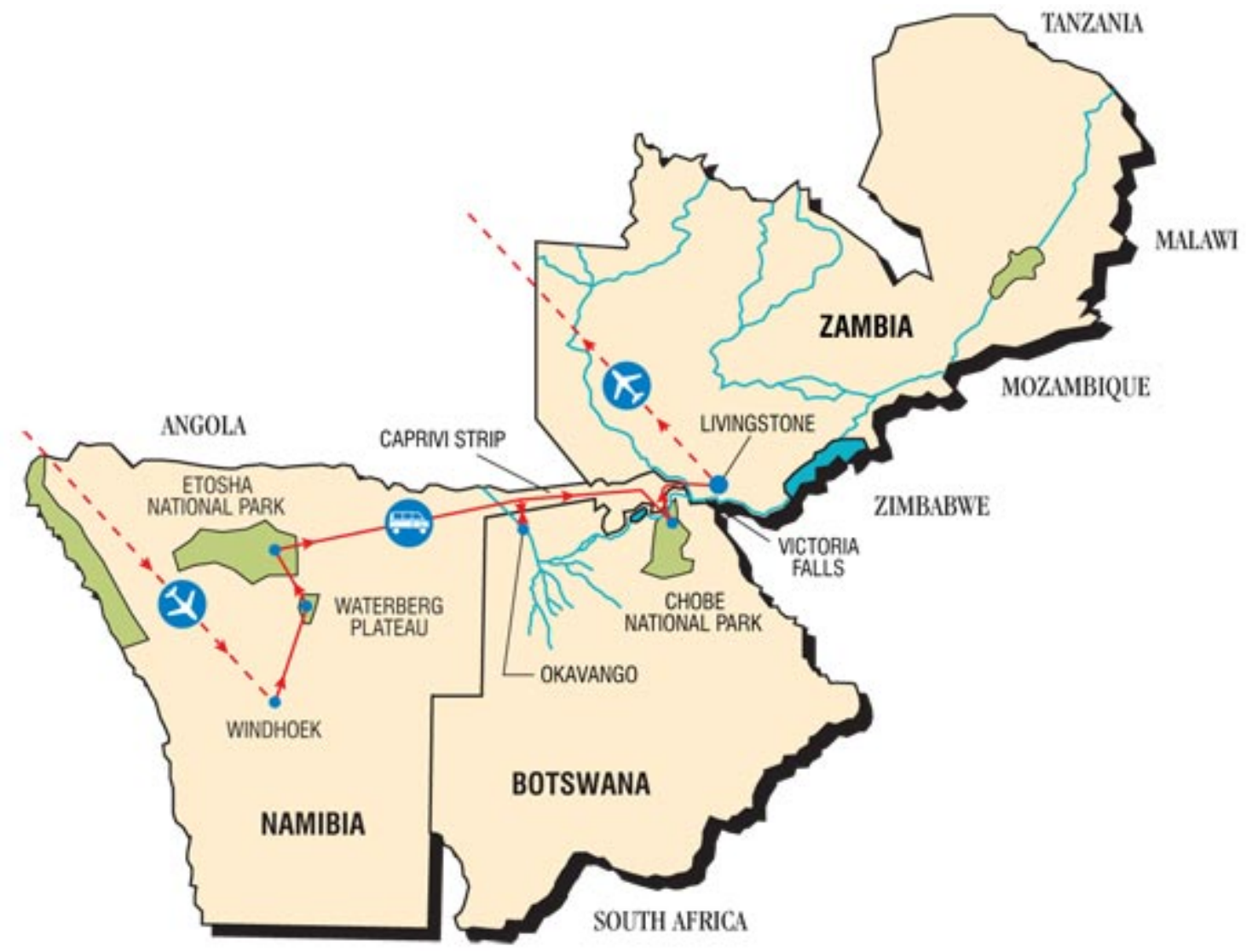

Figure 1. A map of Botswana, Namibia, and Zambia. Source: Naturetrek (2012).

\section{Analytical Framework}

The paper employs a critical discourse analysis in combination with qualitative case study approach (Veal, 1997; J. Hussey \& R. Hussey, 1997; Jennings, 2001) to analyse available data. Critical review of current and relevant literature on the subject matter was carried out. Specifically current existing data from the literatures on CBNRM in three focal southern African countries of Botswana, Namibia, and Zambia were critically analysed with a view to assessing the successes and failures of CBNRM programme implementations in southern Africa. It also determines the nature of the interface among CBNRM, tourism, rural development, and poverty alleviation initiatives. Consequently data analyses were based on case study design (Yin, 2003, p. 111). Common Property Resource (CPR) theory served as the basis for developing a conceptual framework in the context of the paper. The theory places emphasis on how natural resources especially those shared by local communities can be sustainably used.

\section{CBNRM}

Africa is arguably said to be oldest continent; having remained in place since the breakup of panacea 200 million years ago (Bukenya, 2009). Africa has remained as the only landmass with an array of natural resources 
unsurpassed in the world. It has been documented that "much of the world's biodiversity is located in Africa south of the Sahara. In some locations diversity is eight times the world average, four times that of the United States, and twice that of Brazil” (USAID, 2009). It is upon this rich biodiversity that tourism and rural livelihoods of local people are anchored in southern Africa. Perhaps as a result of improper implementation of CBNRM initiatives, these unique natural resources are now under siege; human impacts on biodiversity are increasingly severe. Forest, savannah, and tropical ecosystems are being rapidly degraded, along with national parks, game reserves, and fish. In their quest to gain social, cultural, and economic development, many African countries especially those in southern Africa now grapple with the decline in natural resources and high poverty rates (Mbaiwa, 2011). Yet the CBNRM program is one of the strategies adopted by a number of southern Africa countries to circumvent the threat against biodiversity and enhance poverty alleviation. USAID (2009) documented that CBNRM grew out of the recognition that unsustainable local practices were driving resource degradation in this part of Africa which is also very poor amidst plenty-that existing legal, social, and economic policies in particular, the absence of nationally recognized individual or communal resource tenure rights inhibit sustainable resource use; and governments in developing countries often lack of the financial or institutional resources to adequately manage or regulate natural resource use. The framework thus has three main goals of improving the livelihoods and quality of life of local people and helping to reduce rural poverty; enabling the wise use and conservation of natural resources and ecosystems; and empowering rural communities to make decisions on how to wisely use natural resources (USAID, 2009). In principle, CBNRM is premised on the idea that communities will sustainably manage local resources if they are assured of the ownership of those resources; allowed to use the resources themselves and/or benefit directly from others who use them and are given a reasonable amount of control over management of the resource (Mbaiwa, 2011; Twyman, 2000).

There is however a controversy among scholars as to whether CBNRM is a paradigm shift or a programme (Mbaiwa, 2011). In the context of this paper, CBNRM is discussed as a programme because it is a framework depicting an on-going development concern with a very long life-span. Weaver (2010) stated that a program is different from a project in that a program is a portfolio comprising multiple projects that are managed and coordinated as one unit with the objective of achieving (often intangible) outcomes and benefits for the organization. A project is a temporary entity established to deliver specific (often tangible) outputs in line with predefined time, cost, and quality constraints. That said, each southern African country has a unique name for CBNRM. Examples are the Communal Area Management Programme for Indigenous Resources (CAMPFIRE-Zimbabwe), NRM Project (NRMP/CBNRM-Botswana), Living in a Finite Environment (LIFE—Namibia), and the Administrative Management Design (ADMADE-Zambia). Reasoning from a project point of view, Mbaiwa (2011) affirmed that CBNRM success rate also differs from country to country and from project to project. Widely claimed and arguably so, the CAMPFIRE program has been documented and claimed to have been successful in achieving better conservation and livelihoods during its time (Child, Jones, Mazambani, Mlalazi, \& Moinuddin, 2003; Mbaiwa, 2011). In terms of conservation, Child et al. (2003) rationalize their assertions on the ground that CAMPFIRE triumphed in the protection of an area of wild land roughly equivalent in size to the parks and wildlife estates of Zimbabwe which occupies an area of some $50,000 \mathrm{~km}^{2}$. They further justify their claim in that there was also an increase in the wildlife population in areas reserved for safari hunting. Based on their findings, Child and his colleagues report that wildlife populations increased by about 50\%, with elephants doubling from 4,000 to 8,000 in the CAMPFIRE areas in the first 10 
years from its inception. From the perspective of better livelihoods, CAMPFIRE program's success in this area is justified by its acceptance countrywide where a total of 23 districts established CAMPFIRE projects; CAMPFIRE Association tremendously increased in membership within 10 years in Zimbabwe's 57 Rural District Councils. Also, CAMPFIRE is said to have increased the revenues from safari hunting to US\$2 million annually; and "between 1989 and 2001, CAMPFIRE generated direct income of over US\$20 million, with an economic impact of US\$100 million” (Mbaiwa, 2011). The revenue generated from CAMPFIRE was re-invested in community projects such as building schools in rural areas and buying boreholes to provide water to both human beings and livestock. In addition, revenue has been devolved to participating communities at household levels (Child et al., 2003). Other scholars (Muir-Leresche, Chambati, \& Khumalo, 2003) indicated that by the late 1990s, an estimated 90,000 households (630,000 people) were benefiting from CAMPFIRE revenue. Revenue obtained through CAMPFIRE has further been re-capitalised in the construction of lodges. Child and his team also report that at least 12 high-end tourism lodges have been developed in communal areas with funds generated through safari hunting. These lodges provide employment to rural people of Zimbabwe. Clearly, this shows the extent to which CAMPFIRE has positively impacted on sustainable utilisation of natural resources, rural development, and poverty alleviation in rural Zimbabwe.

From another vantage point, Jones (2004) argued that CBNRM programs attempt to simultaneously address two main issues of natural resources degradation and poverty alleviation. However, their solutions are often seen as being in direct conflict. CBNRM is governed by the philosophy of local-level control of common goods whereby communities play a crucial role in decision-making processes bordering on the sustainable utilisation and management of natural resources (Twyman, 2000). Thus it is safe to affirm that CBNRM is a conservation and rural development strategy, involving community mobilisation and organisation, institutional development, comprehensive training, enterprise development, and monitoring of the natural resource base (Mbaiwa, 2010; Blackie, 2006; Thakadu, 2005; Twyman, 2000). Elsewhere, Rotha et al. (2005) argued that CBNRM is a concept related to a variety of terms, including participatory, community, community-based, collaborative, joint, and popular natural resource management. These concepts are often used interchangeably but may also be used with the intention to emphasise specific characteristics of related approaches. Somehow, the concept of CBNRM tends to be associated with approaches dealing with joint natural resource management, where the local community is the focal point. Sometimes, it has also been applied to designated approaches where local communities play a central but not exclusive role in natural resource management.

Arguing from an adaptive co-management perspective, Borrini-Feyerabend, Pimbert, Farvar, Kothari, and Renard (2004) wrote that:

Co-management (CM) of natural resources is used to describe a partnership by which two or more relevant social actors collectively negotiate, agree upon, guarantee and implement a fair share of management functions, benefits and responsibilities for a particular territory, area or set of natural resources. (p. 69)

DANIDA (2007) supports Borrini-Feyerabend et al. (2004) by reporting that the advantage of the delineation is that it concerned with different ways in which the planning and implementing authority overseeing natural resources can be shared among various social actors, thus refraining from pre-empting any a priori model of resource management.

Indeed, the CBNRM framework is perhaps the major tool for driving community and rural development in southern Africa (Madzwamuse, 2007). Thus, CBNRM is designed and put in place to enable local people 
regulate the use of natural resources available within their environment and appropriate the same for the betterment of community socio-economic and ecological well-being (Mbaiwa, 2010). Tourism business has become one of the major earners of national income for a number of countries in southern Africa. The CBNRM, therefore, serves as an interface between tourism activities and the governments of southern African countries (Mbaiwa \& Stronza, 2010).

\section{The CPR}

The world is presently faced with a myriad of natural resources and environmental management challenges. At the moment, frequent incidents of natural and made disasters such as floods, droughts, degeneration of biodiversity, pollution, loss of agricultural land, loss of wildlife, and overgrazing are now witnessed across the entire globe. One of the popular but controversial thesis explaining these problems is the theory of "CPR", which has become one of the most important bodies of theory steering the management of resources. Ostrom (1990) stated that natural and environmental resources typically present common pool resources characteristics such as that the exploitation by one user reduces resource availability for others (subtractability) and exclusion of additional users is especially difficult and costly (difficulty of exclusion). Fundamentally, the CPR theory is concerned with the way in which resources especially those shared by communities can be sustainably used. Proponents of this theory argue that all resources (such as wild animals, minerals, fish in rivers lakes and oceans, air, water, and forests) held in common will inevitably be overexploited (Ostrom, 1990; Ostrom \& Field, 1999; Bromley, 1992; Gordon, 1954). Given that such resources have no private owner, it is in no one's interest to protect them or use them sustainably. The theory further argues that privately owned property, in contrast to the publicly owned ones, will be conserved. Many renowned economic scholars who have devoted themselves to studying the effects of ownership rights on exploitation rates have concluded that private ownership of natural resources has a number of benefits. In addition to conserving the resources, it ensures their efficient use and reduces transaction costs and overcapitalization (Cheung, 1970; Johnson, 1972; Scott, 1955; Ostrom, 2007). The CPR theory, therefore, perceives the benefit of private property to stem from the fact that secure property rights will wade off externalities. But then, it is more intriguing in some contexts to note that certain community people feel it is "rational" for users to overexploit natural resources than to conserve them (Scott, 1993). Underpinning the "tragedy of the commons", Hardin (1968) is of the opinion that the users of natural resources are caught up in a process that leads to the destruction of the natural assets upon which they (the common people) depend. Given that such resources are not individually managed or controlled, the ability to manage them therefore becomes challenging. Hardin's (1968) model of the tragedy of the common instigates that overexploitation of natural resources by community people will eventually lead to their degradation. Nonetheless, this thinking has been dispelled by scholars who see community people as agents of conservation. They argue that there exist "common-property resource management" strategies through which local people restrict access to the use of natural resources by invoking certain sanctions and procedural rules for their sustainable use (Feeny, Berkes, McCay, \& Acheson, 1990; Berkes, 1989; Pinkerton, 1989, etc.). Consequently, the CBNRM framework is one of the co-adaptive management strategies, which has been employed by community people and other stakeholders in the conservation of natural resources available around local communities. The notion that people would judiciously use what belongs to them informs the school of thought on CBNRM advocacy.

Thus, the CBNRM approach is rooted on the foundation of the common property theory. CBNRM program in southern Africa is somewhat based on the understanding of the principles guiding the sustainable use of 
common resources. Central to the CBNRM hypothesis are the theory and assumptions underlying the political decentralisation of natural resources and poverty alleviation. Boggs (2000) argued that the management of resources by the central government has been ineffective in the past and that the solution to the problems is the CBNRM approach. Decentralisation of resources to local communities has prospect in promoting sustainable resource utilisation and rural development. CBNRM promoters perceive the decentralisation of natural resources as a remedy to the chronic wildlife and other natural resources decline resulting from the central government failings in resource management (Mbaiwa, 2011). The decentralisation of natural resource management implies a process of redistribution of power and the transfer of responsibilities from the central government to rural communities in resource management (Boggs, 2000). This is a shift from the so-called top-down approach to a bottom-up approach in natural resource management. The assumption is that the decentralisation of natural resources to local communities will not only increase local power and control over resources, but it will also improve residents' attitudes towards sustainable use of natural resource and more importantly will also contribute to poverty alleviation (Scott, 1993).

\section{CBNRM Framework in Southern Africa}

By 1980 most countries in southern Africa had become independent and came to the realisation that their natural resources especially wildlife were under the threat of either depletion or extinction. They, therefore, embarked on the search for appropriate programmes that could enhance the protection of the natural resources and benefit accruing to the people therefrom. As such, informal CBNRM initiatives began in Zimbabwe and Namibia in the early 1980s (USAID, 2007b). CBNRM quickly and formally became famous through the CAMPFIRE projects in Zimbabwe. Although Zambia's ADMADE was launched before CAMPFIRE, it remained smaller and less well-known. Indeed, Zimbabwe, Botswana, and Namibia have the largest CBNRM programs, which were formally established through appropriate legislative change or specific programs in 1989, 1992, and 1996, respectively (USAID, 2007b). Countries such as Malawi (1994), Mozambique, and South Africa followed in quick succession, but the programs are smaller and more projects oriented.

As earlier observed, the objective of CBNRM in southern Africa has been the decentralisation of authority over natural resources from the state to communities who live within and around these resources (Jones, 2007). Although the resource scope is now broadening to include other natural resources, CBNRM in this region has focused mainly on wildlife resources and tourism. Whereas the programs in Botswana and Namibia have strongly depended on wildlife and tourism, Zambia projects do include forestry and fisheries (USAID, 2011). Also, USAID (2007a) reported that the emphasis on wildlife and tourism is as a result of communities being severely alienated historically from wildlife resources and which now stand to gain significantly in new income, if given the access. Attention is focussed on the CBNRM activities in Botswana, Namibia, and Zambia in the following sub-sections.

\section{Botswana}

CBNRM was first introduced in Botswana in 1990 through the United States Agency for International Development (USAID), which funded the Natural Resource Management Project (NRMP) together with the Botswana Government. Most CBNRM projects were and still are based on wildlife resources, but a few projects deal with veld products (Mbaiwa, 2011). The first CBNRM project was the Chobe Enclave Community Trust, which began in 1993 and derived revenues from hunting and photo safaris (Jones, 2002). The CBNRM 
framework in Botswana is based on registered community-based organizations (CBOs). The Botswana CBNRM status report indicates a total of 94 legally registered CBOs existed in 2006 (IUCN, 2006). The program covers the entire country; more than 100 villages with more than 135,000 people are involved in CBNRM. Most CBOs, certainly the ones with high revenues, are located in northern Botswana around the tourist destinations/attractions of the Okavango and Chobe/Zambezi rivers. The oldest and largest CBO dealing with veld products is KgetsiyaTsie (KYT) (USIAD, 2007b). A CBNRM Support Program started in 1999 as a joint initiative of International Union for Conservation of Nature (IUCN) and the Netherlands Development Organization (SNV) and was later supported by the World Wide Fund for Nature (WWF) (2004-2006). In the 1990s and 2000s the CBNRM program in Botswana experienced a boom in registered CBOs.

USAID (2007b) claimed that revenues from commercial resource use were estimated to be P19.3 million and subsistence activities generated P16.2 million in-kind income in 2005 alone! Trophy hunting is the most important commercial activity (P11.9 million) followed by tourism (P3.1 million), sale of veld products (P0.7 million), and crafts (P0.6 million). In terms of employment generation, USAID reports that CBNRM employment is modest with an estimated 800 jobs, roughly two-thirds of which are located with the joint venture partners (520) and one-third with the CBOs. The USAID report also denotes that the CBNRM indicators show that the overall development impact of the program is limited. Around 1.2 percent of the adult population in CBNRM areas is employed through CBOs or joint venture partnerships (JVPs). The CBNRM benefits translate to a modest amount of around P240 per person per year. This figure, however, falls far short of CBNRM potential in contributing to community benefits and better livelihoods of the people. The problem here like in other southern Africa countries is lack of evaluation of what works and what does not work in CBNRM programs. Overall, the CBNRM program in Botswana has rapidly grown in the past two decades and diversified its natural resource base (wildlife, veld products, tourism, rangelands, and rural development). But then, this has not fully contributed to rural development and sustainable livelihoods. Nonetheless, Mbaiwa (2004) argued that CBNRM in the Okavango Delta has succeeded in terms of income generation, employment creation, the establishment of local institutions meant to ensure local participation in NRM, tourism development, and determination of economic valuation of natural resources.

\section{Namibia}

In Namibia, CBNRM informally commenced in the late 1980s with the formation of the Integrated Rural Development and Nature Conservation (IRDNC) project. This initiative was based on the experience of a community game-guard system and also on the need to combat poaching and procure wildlife-tourism benefits for local communities (Jones, 1999). After the independence in 1990, IRDNC assisted the newly established Ministry of Wildlife, Conservation and Tourism (now the Ministry of Environment and Tourism or MET) in conducting socio-ecological surveys in several game areas (Child et al., 2001). The findings of the study showed that local people needed incentives to become involved in utilising their resources sustainably. Thus, CBNRM became a policy goal. However, funding was needed to implement these recommendations. In 1993, the Living in a Finite Environment (LIFE) Program was launched, administrated by WWF-US, and supported by USAID and the Namibian government (Jones \& Mosimane, 2007). A LIFE Steering Committee (comprising membership of several Namibian NGOs) helps in directing the initiative's activities. It is instructive to note that Namibia's CBNRM programme is institutionally strong, having a well-integrated government co-ordinating body and several strong Namibian NGO support providers (USAID, 2007a). However, some reservations are expressed in 
certain quarters that the legislation is not comprehensive; the initiative translates poorly into action; there are communication failures on the part of government agencies; and more NGO expertise is needed. In spite of these seeming shortcomings, Namibia's programme comprises the basics of a national CBNRM movement, which makes the consequent process of participation for communities easier (Jones \& Mosimane, 2007).

With progressive government policies, well-co-ordinated networks of service organisations and community-based tourism enterprises, and several capable NGOs either established or being improved, Namibia's CBNRM program is well structured and effective (USAID, 2007b). In Namibia some innovative strategies have been utilised. These include the Community Game Guard (CGG) and Community Resource Management (CRM) systems, employment of business advisors, games for capacity-building and facilitation, and a well-constructed tourism training programme. But all this does not suggest that there is no stumbling-block in implementation of the program. For instance, problems associated with land tenure rights remain unresolved, basic education is still needed to enable the majority of conservancy members to effectively acquire NRM skills, and co-ordination and service provision still need some improvement. However, Namibia has a strong basic structure of CBNRM activities and implementing organisations, which with a few more years of experience, should see the programme through the withdrawal of donor support (Jonesand \& Mosimane, 2007).

\section{Zambia}

The Zambia's National Park and Wildlife Service (NPWS) now (Zambia Wildlife Authority, ZAWA) convened the Lupande Development Workshop in September 1983 to discuss management strategies for combating the extreme poaching problem prevalent at the time (Jones et al., 1998). The Lupande Research project, examining elephant management outside of the South Luangwa National Park, highlighted the need to involve local residents in environmental conservation projects and was the catalyst for CBNRM in Zambia. Jones and his colleagues further report that two initiatives resulted from that workshop: the Luangwa Integrated Research and Development Project (LIRDP) and the Administrative Management Design (ADMADE) for Game Management Areas (GMAs). It is noteworthy to mention that Zambia's CBNRM program, especially ADMADE, is unique in the region for being a largely indigenous initiative. Essentially, the Zambian government directs the efforts while donor funding and NGO involvement have been somewhat limited (Jones \& Mosimane, 2007).

Zambia's CBNRM is also different because of the severely limited infrastructure in rural areas; a large portion of benefits received is expended on physical development like roads and schools. Zambia's CBNRM (i.e., ADMADE) differs from other programmes in the region in that it is largely a local initiative. After the initial five-year grants, WWF and USAID's aid was not renewed, and USAID now only assists with some seed money for vehicles and Nyamaluma's ${ }^{1}$ running expenses (USAID, 2011). ADMADE covered $80 \%$ of its own costs (USAID, 2007b). Rather than being a donor-driven project for the sake of community governance and wildlife conservation, ADMADE was established because NPWS lacked the funds to effectively manage natural resources in communal areas. Local community people who are knowledgeable, ever-present and serve as cost-effective "employees" were enlisted to help after being trained at Nyamaluma. Thus, ADMADE had consciously focused on hunting safaris for its sizeable rate of returns on low inputs. Money earned is divided into a $40 \%$ : $35 \%$ : $25 \%$ sharing formula. The largest percentage (i.e., $40 \%$ ) is returned to the GMA for actual wildlife management including village scout salaries, vehicle running costs, and conservation monitoring activities. The $35 \%$ is given to local communities strictly for self-directed development projects like schools, clinics, roads, etc.,

\footnotetext{
${ }^{1}$ Nyamaluma is one of the Zambian communities where CBNRM is being implemented.
} 
and other basic infrastructure, which the government has not been able to provide in rural areas. The remaining $25 \%$ goes into the Wildlife Conservation Revolving Fund housed by ZAWA. This money is being used for ADMADE administration costs and as capital replacement in units that are not yet self-sufficient (USAID, 2007b). As the information contained on Zambia's CBNRM is rather scanty, not many conclusions can be made about the national programme. Nonetheless, ADMADE catches attention for its inward looking attribute, local content, and very near self-sufficiency (in terms of funding) in the region. This avails it as quite a unique model of some sort. Already, steps are being taken to improve its democratic structures and devolve benefits to communities. Several other organisations are becoming involved in CBNRM. And fisheries as well as wetlands — rare in the rest of the region — are being targeted. Indeed, SNV is one of the few organisations actively working in the field with fisheries and forestry co-management schemes (USAID, 2011).

\section{Strengths and Weaknesses of CBNRM Programs in Southern Africa}

As earlier observed, CBNRM programs and projects have been in existence in southern Africa since the 1980s. While their unique blend of environmental, economic, and social potentials have been recognised and acknowledged, there exist some successes and failings of these initiatives, which cannot go without mention.

For instance, CBNRM activities in Botswana present mixed results. Some of the CBNRM projects (e.g., in the Okavango Delta) have collapsed, while others have succeeded and have significantly benefited participating villages economically (Mbaiwa, 2010). Mbaiwa (2011) provided an example of the Sankoyo Village CBNRM project (involving photographic and safari hunting tourism) as a success story in terms of generating benefits such as income and employment opportunities. One of the facts emerging from the review of CBNRM in Botswana (2003) is that the initiative has significantly improved the communities' appreciation of the value of natural resources. Specifically, there has been an acute shift of attitudes towards natural resources, particularly wildlife as a result of the CBNRM orientation. Prior to the implementation of the CBNRM programme, most communal natural resources had fallen prey to the so-called open access, where the use of resources was not controlled. This applied to most veld products that were not regulated under the 1974 Agricultural Resources Conservation Act, and for communal rangelands in the proximity of villages that were not controlled by private borehole owners. However the main problems in Botswana's CBNRM are fund mismanagement by CBOs, increased devolution of rights, and lack of capacity building for the CBOs (National CBNRM Forum, 2005).

In Namibia, CBNRM has made a considerable difference in the protection and recovery of wildlife species such as the desert-dwelling black rhino and elephant. Due to conservation efforts through CBNRM, there are more huntable games available for community use, sales to trophy hunters, and live sales which have contributed to better community livelihoods. CBNRM has also promoted wildlife and tourism as a way of using land in communal areas and demonstrated the economic value of these resources to the national economy (Boudreaux \& Nelson, 2011). Private enterprises' contributions to the national economy are conservatively estimated at US $\$ 5.5$ million. These include turnover of joint venture lodges, sustainable trophy hunting, thatching grass, and other direct income sources. Tourist lodges, camps, guide services, and related businesses such as handicraft production employed 547 full-time and 3,250 part-time workers. In some regions, it is estimated that conservancies directly provided 28 percent of area employment in 2003 (USAID, 2005).

Namibian communities have benefited greatly from conservancies. Income has increased from about 500,000 Namibian dollars (1996) to more than 14 million (US\$2.5 million) in 2004. About half of this constituted 
direct cash dividend or social programs (such as school improvements, new water pumps, or diesel fuel for operating pumps). The additional benefits were earned by individual households through wages from conservancy-related jobs and enterprises. In the Kunene region, a 29 percent increase in per capita income has been recorded due to the combination of direct and indirect effects of CBNRM, suggesting a significant role for conservancies in alleviating rural poverty (USAID, 2007a). However, many problems still remain. Firstly, the enormous growth of registered conservancies has meant that government and NGOs are finding it difficult to provide enough managerial and technical support to them (USAID, 2007a). Secondly, over-reliance on external aid has been identified as a major challenge; donor organisations have made a significant contribution to helping conservancies get off the ground through the provision of management and technical training as well as buildings and equipment (USAID, 2007a). Whether these conservancies will last and demonstrate that CBNRM is able to support directly the livelihoods of rural communities in the long term is not yet known.

In Zambia, the rights to benefit from wildlife have improved over the past years due to CBNRM activities, which also attempted to address issues of rural poverty and unemployment in order to gain local support for natural resources conservation. In the past, local communities were alienated from benefiting from natural resources, including land. Current legislation now has provisions on community rights to benefit from natural resources. The Zambia Wildlife Act No. 12 of 1998 allows greater participation of local communities, thus establishing their rights to use and manage natural resources in GMAs and Open Areas. This includes provisions for local-level participation in developing management plans (USAID, 2011) for development purposes. The elephant population in the Luangwa Valley, which was the focus of conservation efforts at the genesis of CBNRM, shows positive growth since the inception of the initiative. CITES (2010) reported that the Luangwa system now supports the majority of Zambia's elephant populations that have been increasing and, which now currently stand at $18,634 \pm 3,592$. This constitutes $72 \%$ of Zambia's elephant populations and is a significant increase from the estimated population of about 9,000 in the early 1980s.

However, the challenges to Zambia's CBNRM include failure by many of the stakeholders to acquire and utilize indigenous knowledge; inadequate legal framework to support benefit sharing with respect to forest resources; and overall benefits to local communities are insufficient. Advocacy by civil society will play a critical role in strengthening the policy and legal framework that govern natural resource use and management. Due to inadequate revenues accruing from wildlife resources as a result of government involvement, which wields the greater control, households do not receive direct dividends from wildlife management. Yet, direct dividends imply revenue sharing as compensation for living with a resource and bearing the costs associated with it.

In summary, on the one hand, the success stories (i.e., those aspects of CBNRM that have worked) abound in all the countries. These include reduction in wildlife poaching and improved local community attitudes towards wildlife and natural resources; increased wildlife; community development especially in rural areas; contribution to improved community livelihoods; and increased conservation of natural resources.

On the other hand, those aspects of the initiative that have not worked (i.e., daunting challenges) include: mismanagement of funds by CBOs; lack of full support from national governments in terms of funding —a lot of CBNRM have relied on partnership with donor agencies; lack of technical skills for the CBOs; uncoordinated linkages with other developmental programs; and dearth of policies, which incorporate CBNRM programs in the overall national development plans. 


\section{Tourism and Rural Development: Do They Interface With CBNRM and Poverty Alleviation in Southern Africa?}

CBNRM is an incentive-based conservation philosophy that links conservation of natural resources with rural development (Blackie, 2006; Mbaiwa, 2010; Swatuk, 2005; Thakadu, 2005; Twyman, 2000). The basic assumption of CBNRM is that a community will manage its natural resource base sustainably if it gains direct benefits arising from its use. The failings of centralized approaches to NRM in a bid to arrest irretrievable losses of these natural endowments around the world during the colonial and post-independence periods led to a search for an alternative CBNRM regime. From tourism perspective, tourism literatures since the 1980s, have made advocacies for the inclusion and involvement of local communities in tourism as local residents are seen as a key resource in sustaining the product (Hardy, Beeton, \& Pearson, 2002). Community participation is often regarded as one of the most essential tools of tourism business if the industry is to make any substantial contribution to the national development of a country (Lea, 1988). Therefore, there exists a veritable interface among tourism, rural development, and CBNRM. For some, community participation in tourism ensures environmental sustainability (Woodley, 1993), better opportunities for local people to gain benefits from tourism taking place in their locality, positive local attitudes and the conservation of local resources (Tosun, 2006). Participation is emphasised at the local level to facilitate physical development, the inclusion of community wishes in tourism planning and development and to ensure economic returns from the industry (Murphy, 1985).

Although CBNRM was initially set up as a conservation approach, the rural development aspect of the initiative has become more prominent (Arntzen, Sethogile, \& Barnes, 2007). It is based on the common property management theory which discourages open access resource management; it promotes resource ownership, control, and use by local communities (Rihoy \& Steiner, 1995). In Botswana, CBNRM is seen as a development approach that supports natural resource conservation and the alleviation of poverty through community empowerment and the management of resources for long-term social, economic, and ecological benefits (Government of Botswana, 2000). The utilization of natural resources through CBNRM can lead to several benefits, which are interrelated and help to address different needs within a community. The creation of employment is one of the most important strategies to alleviate poverty as well as bring social security in the lives of the people resident in remote areas. Other benefits apart from employment can come in a variety of forms: cash disbursement, self-reliance of community projects, local empowerment, enhancement of self-esteem and confidence, strengthening of the village identity and culture. The community-based approach to NRM is premised upon its ability to alter local behaviour and practices in ways that conform to the attainment of pre-determined conservation and community development goals (Gibson \& Marking, 1995).

\section{CBNRM in the Okavango Delta}

The Okavango Delta of Botswana is a vast inland delta system that receives an annual flood from the highlands of southern Angola (see Figure 2). It fluctuates in area coverage from 15,000 $\mathrm{km}^{2}$ during the flood to $6,000-8,000 \mathrm{~km}^{2}$ during the dry season. Geologically the Okavango is a young system (approximately 10,000 years old), which before major geologic uplifting formed a drainage channel into a great lake called the Makgadikgadi (Merron, 1991). Although CBNRM in the Okavango Delta is noted to have made some positive impacts on poverty alleviation and people's livelihoods, it has also been criticised by different scholars for its several weaknesses (Mbaiwa, 2011). Swatuk (2005) and Blackie (2006) argued that CBNRM has not realized its 
objectives of conservation and rural development. Instead, it has been used as an instrument by donor conservation agencies and governments of industrialized countries to perpetuate the global domination of developing countries. While Taylor (2000) noted the relegation of minority groups such as the Basarwa of Gudigwa from deriving benefits from CBNRM, Twyman (2000) argued that CBNRM in Ngamilaland ${ }^{2}$ is not fully developed to yield significant benefits to residents. Despite these criticisms, CBNRM in the Okavango Delta is one approach that is introducing local participation and benefits from tourism development, particularly in rich wildlife areas (Kgathi, Ngwenya, \& Wilk, 2007; Mbaiwa, 2004; 2011). While this may be the case, available studies on CBNRM in the Delta have not adequately shown the contribution of CBNRM to rural development (L. I. Magole \& L. Magole, 2005; Mbaiwa, 2005; 2011; Thakadu, 2005).

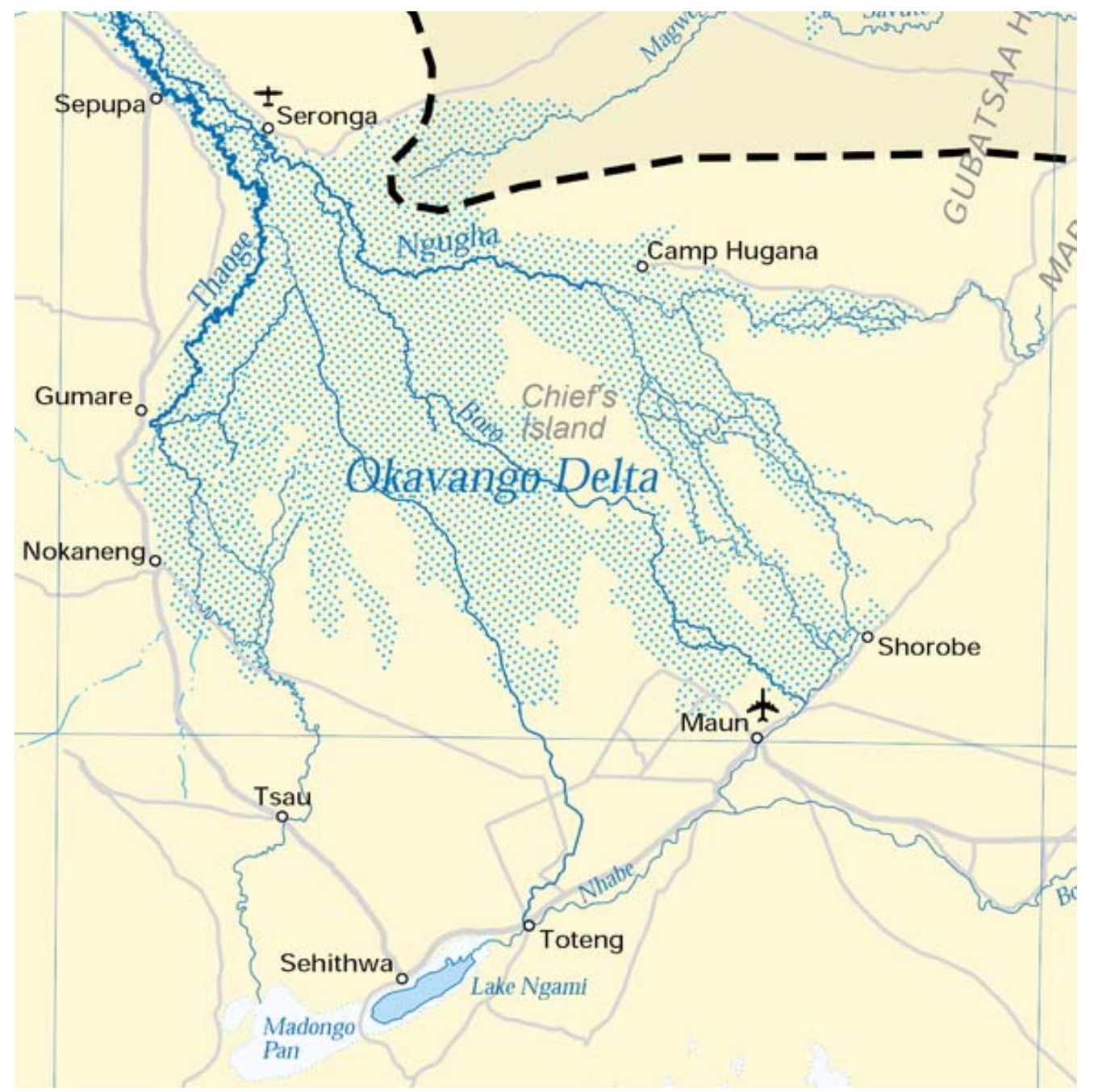

Figure 2. Map showing the Okavango Delta of Botswana. Source: Wikipedia (2014).

\section{Local Knowledge, CBNRM, and Tourism in Southern Africa}

Within addition to the attention given to participation at the local level, there is now a growing focus on the role and importance of culture and local knowledge (also known as indigenous or traditional knowledge) in the

\footnotetext{
${ }^{2}$ Ngamilaland is a district in north-western Botswana where CBNRM program looms large.
} 
development process (Kolawole, 2001; 2009). While on the one hand, this has led to an understanding of the cultural foundation and context for local natural resource management and the importance of local knowledge for CBNRM activities, culture and local knowledge on the other hand, are now increasingly used as a tool for organizing local people around specific CBNRM activities. Local knowledge also addresses local natural resource management regimes, including traditional rights to natural resources (Lars, 2001).

The 1998/1999 World Development Report affirms that knowledge, not capital, is very crucial in sustainable social and economic development. Building on local knowledge, the basic component of any country's knowledge infrastructures, is the first step to mobilize such capital. Therefore, development activities, especially those that aim to benefit the poor directly need to prioritize local knowledge in the design and implementation stages of the process (World Bank, 1999). Madzwamuse and Fabricius (2004) argued that local knowledge in the management of natural resources in Botswana by the Basarwa and other indigenous communities has until recently been ignored. But the commitment and relatively recent inclusion of local communities in the management of natural resources show how governments are appreciating local knowledge. Knowledge of society and of community plays a very important role in the development process because it ensures the stability and invulnerability of traditional social relations. World Bank (1999) opined that indigenous knowledge is an important component of rural poor people's life. It is an integral part of the local ecosystem. Local knowledge is a key element of the "social and human capital" of the poor; their main asset to invest in the struggle for survival, to produce food, to provide for shelter, or to gain control of their own lives. Local knowledge also provides problem-solving strategies for local communities and helps shape local visions and perceptions of environment and society (Warren, 1990; 1991).

It follows then that rural tourism, CBNRM, and local knowledge are not mutually exclusive. Local knowledge is important for both the local communities and the global community. Development workers/partners need to recognize the role of local knowledge, understand its workings in the context of the local communities, and systematically integrate the effective and promising aspects of such practices into development programs such as CBNRM (Manyozo, 2010; Kolawole, 2009).

\section{Concluding Reflections}

Some general conclusions are drawn from the issues raised in the paper. In most part of southern Africa, natural resources and tourism currently provide the opportunity to generate the highest financial benefits compared to other resources. But the benefit to households' remains low and the cost implications of living with natural resources (wildlife) remain high while community proprietorship over natural resources remains weak.

This situation arises mainly through the way in which CBNRM programs have developed in the region. The main conceptual foundations of CBNRM-economic incentives, devolution, and proprietorship have only been applied in part. Governments prefer co-management and revenue sharing approaches where they retain a high degree of control over natural resources and a large share of the income from its use. Governments still play a major role in decision-making regarding the use of natural resources and in many cases usufructs are conferred by administrative decree and management agreements rather than through a rights-based approach entrenched in legislation. As a result, many CBNRM activities in the region demonstrate characteristics of co-management rather than largely autonomous community management.

Nevertheless CBNRM as a strategy for rural (tourism) development proves to be a veritable instrument for achieving community well-being in southern Africa. Nonetheless, there remain numerous but pertinent issues 
that need to be addressed. These include amongst other issues, inconsistencies in law and policy, conflicts between community and private interests, unresolved imperatives of land reform, confusion around organisational roles, and responsibilities of the state. Others are limited training and capacity building for CBOs, insecurity of tenure, stakeholder conflicts, mismanagement of funds, and problems of how to use and equitably distribute the financial benefits to individual households.

It is, therefore, necessary for the CBNRM initiatives to focus on training in order to improve the participation of local communities in CBNRM initiatives. At the same time, there is need to carry out evaluation studies on changes in attitudes towards natural resources, and on the extent to which the CBNRM initiatives have influenced natural resources conservation. There is also a need to determine the extent to which CBNRM could contribute to rural development with a view to enabling proper and adequate development planning. Household benefits and income generation apart, emphasis needs to be placed on local-level governance of CBNRM institutions and skills development, which are essential components that are often overlooked in development practice.

\section{References}

Arntzen, J., Setlhogile, T., \& Barnes, J. (2007). Rural livelihoods, poverty reduction, and food security in Southern Africa: Is CBNRM the answer?. Washington, D.C.: International Resources Group.

Ashley, C. (2000). The impact of tourism on rural livelihoods: Namibia's experience. ODI Working Paper 128, Overseas Development Institute, London.

Barnes, J. (1998). Alternative uses for natural resources in Botswana: Wildlife utilisation. In J. Hermans, \& D. Nteta (Eds.), Botswana in the 21st century (pp. 323-339). Gaborone: Botswana Society.

Berkes, F. (1989). Common property resources: Ecology and community-based sustainable development. London: Belhaven Press.

Blackie, P. (2006). Is small really beautiful? Community-based natural resource management in Malawi and Botswana. World Development, 34, 1942-1957.

Boggs, L. P. (2000). Community power, participation, conflict and development choice: Community wildlife conservation in the Okavango region of northern Botswana. Discussion Paper No. 17, IIED, Maun.

Borrini-Feyerabend, G., Pimbert, M., Farvar, M. T., Kothari, A., \& Renard, Y. (2004). Sharing power: Learning-by-doing in co-management of natural resources throughout the world. Teheran: IIED, IUCN/CEESP, Cenesta.

Boudreaux, K., \& Nelson, F. (2011). Community conservation in Namibia: Empowering the poor with property rights. Oxford: Blackwell Publishing.

Bromley, D. (1992). Making the commons work. San Francisco, C.A.: Institute for Contemporary Studies.

Bukenya, F. (2009). African tourism natural resource need stringent protection to avoid grave danger for future tourism to flourish. $\quad$ Retrieved from http://www.articlesbase.com/vacation-rentals-articles/african-tourism-natural-resource-need-stringent-protection-to-avoid-gr ave-danger-for-future-tourism-to-flourish-837303.html\#ixzz1Y8xYgzV6. Date Accessed 16/09/2011

Cheung, S. N. S. (1970). The structure of a contract and the theory of a non-exclusive resource. Journal of Law and Economics, 13(1), 45-70.

Child, B., Jones, B., Mazambani, D., Mlalazi, A., \& Moinuddin, H. (2003). Final evaluation report. Zimbabwe Natural Resources Management Program—USAID/Zimbabwe Strategic Objective No. 1, Washington, D.C., USA.

CITES. (2010). Doc. 68 annex 6b-Report of the panel of experts on the African elephant on the review of the proposal submitted by Zambia to transfer its national population of Loxodonta Africana from appendix I to appendix II. Retrieved from http://www.cites.org/eng/cop/15/doc/E15-68A06b).pdf

DANIDA. (2007). Community-based natural resource management. Ministry of Foreign Affairs Denmark, Technical Advisory Service, Technical Note.

Feeny, D., Berkes, F., McCay, B. J., \& Acheson, J. M. (1990). The tragedy of the commons: Twenty-two years later. Human Ecology, 18(1), 1-14. 
Fernandez-Gimenez, M. E., Hays, J. U., Huntington, H. P., Andrew, R., \& Goodwin, W. (2008). Ambivalence toward formalizing customary resource management norms among Alaska native beluga whale hunters and Tohono O’odham livestock owners. Human Organization, 67(2), 137-150.

Gibson, C., \& Marking, A. (1995). Transforming rural hunters into conservationists: An assessment of community-based wildlife management programs in Zambia. World Development, 23(6), 118-140.

Gordon, H. (1954). The economic theory of a common property resource: The fishery. Journal of Political Economy, 62, 124-142. Government of Botswana. (2000). Community-based natural resource management policy. Gaborone: Government Printer.

Hardin, G. (1968). The tragedy of the commons. Science, 162, 1243-1248.

Hardy, A., Beeton, R., \& Pearson, L. (2002). Sustainable tourism: An overview of the concept and its position in relation to conceptualisations of tourism. Journal of Sustainable Tourism, 10(6), 475-496.

Hussey, J., \& Hussey, R. (1997). Business research: A practical guide for undergraduate and postgraduate students. London: Macmillan.

IUCN. (2006). Botswana: The CBNRM status report. Retrieved from http://www.cbnrm.bw/publications/Proceedings\%20of\%20the\%204th\%20National\%20CBNRM\%20Conference\%20and\%20 CBNRM\%20Status\%20Report.pdf

Jennings, G. (2001). Tourism research. Sydney: John Wiley \& Sons.

Johnson, O. E. G. (1972). Economic analysis, the legal framework and land tenure systems. Law and Economics, 15, $259-276$.

Jones, B. (2002). Chobe Enclave: Lessons learnt from a CBNRM project 1993-2002. CBNRM Network Occasional Paper No. 7 , CBNRM Support Program SNV/IUCN.

Jones, B. T. B. (1999). Community management of natural resources in Namibia. IIED Issue Paper No. 90.

Jones, B. T. B. (2004). CBNRM, poverty reduction, and sustainable livelihoods: Developing criteria for evaluating the contribution of CBNRM to poverty reduction and alleviation in southern Africa. Commons Southern Africa Occasional Paper Series No. 7, Centre for Applied Social Sciences and Programme for Land and Agrarian Studies.

Jones, B., \& Mosimane, A. (2007). Promoting integrated natural resource management as a means to combat desertification. The LIFE Project and Namibian CBNRM. IUCN/USAID FRAME.

Kgathi, D. L., Ngwenya, B. N., \& Wilk, J. (2007). Shocks and rural livelihoods in the Okavango Delta, Botswana. Development Southern Africa, 24(2), 289-308.

Kolawole, O. D. (2001). Local knowledge utilization and sustainable rural development in the 21st century. Indigenous Knowledge and Development Monitor, 9(3), 13-15.

Kolawole, O. D. (2009). Situating local knowledge within development agenda: Some reflections. Retrieved from http://journals.cdrs.columbia.edu/consilience/index.php/consilience/article/view/93/19

Lars, T. S. (2001). Community-based natural resource management: Knowledge management and knowledge sharing in the age of globalization. Retrieved from http://www.cbnrm.net

Lea, J. (1988). Tourism development in the Third World. London: Routledge.

Madzwamuse, M. (2007). An overview of CBNRM in Southern Africa. IUCN Rosa/SASUG.

Madzwamuse, M., \& Fabricius, C. (2004). Local ecological knowledge and the Basarwa in the Okavango Delta: The case of Xaxaba, Ngamiland District. In C. Fabricius, \& E. Koch (Eds.), Rights, resources and rural development: Community based natural resource management in southern Africa. Earthscan, London.

Magole, L. I., \& Magole, L. (2005). Ecotourism and socio-economic development of Basarwa: The case of Gudigwa village. Gaborone: University of Botswana \& University of Tromso Basarwa Collaborative Programme.

Manyozo, L. (2010). The day development dies, viewpoint. Development in Practice, 20(2), 265-268.

Mbaiwa, J. E. (2004). The success and sustainability of community-based natural resource management in the Okavango Delta, Botswana. South African Geographical Journal, 86(1), 44-53.

Mbaiwa, J. E. (2005). Enclave tourism and its socio-economic impacts in the Okavango Delta, Botswana. Tourism Management, 26, 157-172.

Mbaiwa, J. E. (2010). Tourism, livelihoods and conservation: The case of the Okavango Delta, Botswana (p. 188). Saarbrucken: Lambert Academic.

Mbaiwa, J. E. (2011). The effects of tourism development on the sustainable utilisation of natural resources in the Okavango Delta, Botswana. Current Issues in Tourism, 14(3), 251-273.

Mbaiwa, J. E., \& Stronza, A. L. (2010). The effects of tourism development on rural livelihoods in the Okavango Delta, Botswana. Journal of Sustainable Tourism, 18(5), 635-656. 
Merron, G. S. (1991). The ecology and management of the fishes of the Okavango Delta, Botswana, with particular reference to the role of seasonal flooding (Ph.D. Thesis, Rhodes University, Grahamstown).

Moganane, B. O., \& Walker, K. P. (1995). The role of local knowledge in the management of natural resources with emphasis on woodlands, veld products and wildlife: Botswana case study. Gaborone: Forestry Association of Botswana.

Mordi, R. (1991). Public attitudes towards wildlife in Botswana. New York, N.Y.: Garland Publishing.

Muir-Leresche, B. I., Chambati, W., \& Khumalo, A. (2003). An analysis of CAMPFIRE revenue generation and its distribution: The first decade (1989-2000). World Wide Fund for Nature Southern Africa Regional Programme (WWF-SARPO) Report, Harare, Zimbabwe.

Murphy, P. E. (1985). Tourism: A community approach. New York and London: Methuen.

National CBNRM Forum. (2005). The way forward for CBNRM in Botswana. A Discussion Paper of the National CBNRM Forum.

Naturetrek. (2012). A map of Botswana, Namibia, and Zambia. Retrieved from https://www.naturetrek.co.uk/website/404.aspx

Ostrom, E. (1990). Governing the commons: The evolution of institutions for collective action. New York, N.Y.: Cambridge University Press.

Ostrom, E. (2007). The challenge of crafting rules to change open access into managed resources. Workshop in Political Theory and Policy Analysis, Indiana University.

Ostrom, E., \& Field, B. (1999). Revisiting the commons: Local lessons, global changes. Science, 84, 278-282.

Perkins, J. S. (1996). Botswana: Fencing out of the equity issue, cattle posts and cattle ranches in the Khalahari Desert. Journal of Arid Environments, 33, 503-517.

Perkins, J. S., \& Ringrose, S. M. (1996). Development co-operation's objectives and the beef protocol: The case of Botswana. A Study of Livestock/Wildlife/Tourism/Degradation Linkages. Gaborone: University of Botswana.

Pinkerton, E. (1989). Co-operative management of local fisheries. Vancouver: University of British Columbia Press.

Rihoy, E., \& Steiner, A. (1995). The commons without tragedy? Strategies for community-based natural resources management in Southern Africa. Proceedings of the Regional Natural Resources Management Annual Conference. Kasane: SADC Wildlife Technical Co-ordinating Unit.

Rotha, K. S. et al. (2005). Understanding key CBNRM concepts. In K. S. Rotha et al. (Eds.), The development of community based natural resource management (CBNRM) in Cambodia. Selected Papers on Concepts and Experiences, CBNRM Learning Initiative 2005.

Scott, A. (1955). The fishery: Objectives of sole ownership. Journal of Political Economy, 63, 116-134.

Scott, J. C. (1993). Everyday forms of resistance. Occasional Paper Series, 15, 1-33.

Soaftestad, L. T. (2001). Aligning means and needs: On cultures, ICT and knowledge in development corporation. Retrieved from http://www.cbnrm.net/resources/papers

Swatuk, L. A. (2005). From "project" to "context": Community based natural resource management in Botswana. Global Environmental Politics, 5, 95-124.

Taylor, M. (2000). Life, land and power: Contesting development in Northern Botswana (Ph.D. Thesis, University of Edinburgh, Edinburg).

Thakadu, O. T. (2005). Success factors in community-based natural resource management projects' mobilization in northern Botswana: Lessons from practice. Natural Resource Forum, 29(3), 199-212.

Tosun, C. (2006). Expected nature of community participation in tourism development. Tourism Management, 27(3), $493-504$.

Twyman, C. (2000). Participatory conservation? Community-based natural resource management in Botswana. The Geographical Journal, 166(4), 323-335.

USAID. (2004). Case study: Community-based natural resource management in Namibia. USAID/EGAT Seminar Series: Natural Resources Management and Poverty Reduction.

USAID. (2005). The CBNRM programme and related projects. Retrieved from http://www.usaid.org

USAID. (2007a). Centre for applied research 2007: Community-based natural resource management, rural livelihoods, and environmental sustainability. Phase Three Botswana Country Report, Prepared for IUCN-South Africa and USAID FRAME.

USAID. (2007b). Rural livelihoods, poverty reduction, and food security in southern Africa: Is CBNRM the answer?. Washington, D.C.: USAID.

USAID. (2009). Chapter 2: Community-based natural resource management (CBNRM). USAID Africa Bureau's Environmental Compliance and Management Support (ENCAP) Program, Task Order No. 11.

USAID. (2011). Community based natural resource management: Stocktaking assessment. Washington, D.C.: Zambian Profile. 
Veal, A. J. (1997). Research methods for leisure and tourism: A practical guide. London: Pitman Publishing.

Warren, D. M. (1990). Indigenous knowledge and development. Washington, D.C.: World Bank.

Warren, D. M. (1991). Using indigenous knowledge in agricultural development (pp. 1-34). Washington, D.C.: World Bank.

Weaver, P. (2010). Understanding programs and projects: There's a difference. Retrieved from http://www.mosaicprojects.com.au/PDF_Papers/P078_Programs_Projects_Full_Paper.pdf

Wikipedia. (2014). Okavango Delta. Retrieved from http://en.wikipedia.org/wiki/Okavango_Delta

Woodley, A. (1993). Tourism and sustainable development: The community perspective. In J. G. Nelson, R. Butler, \& G. Wall

(Eds.), Tourism and sustainable development: Monitoring, planning, managing (pp. 135-147). Waterloo: University of Waterloo, Heritage Resources Centre.

World Bank. (1999). The international workshop on community-based natural resources management (CBNRM). Retrieved from http://www.cbnrm.net/library/documents/may98workshop_report.pdf/

Yin, R. K. (2003). Case study research: Design and methods. Thousand Oaks, Calif.: SAGE Publications. 